\title{
Light acclimation and photosynthetic response of beech (Fagus sylvatica L.) saplings under artificial shading or natural Mediterranean conditions
}

\author{
Julien PARELLE ${ }^{\mathrm{a}, \mathrm{b}}$, Jean-Philippe ROUDAUT ${ }^{\mathrm{a}}$, Michel DUCREY ${ }^{\mathrm{a}}$ \\ a INRA, Unité de Recherches Forestières Méditerranéennes, Avenue A. Vivaldi, 84000 Avignon, France \\ b Present address: UMR INRA-UHP Écologie et Écophysiologie Forestières, INRA - Centre de Nancy, 54280 Champenoux, France
}

(Received 23 June 2005; accepted 29 September 2005)

\begin{abstract}
Acclimation of beech (Fagus sylvatica L.) to different light conditions was studied in natural regeneration below black pine canopies (Pinus nigra ssp. nigricans) in Mont-Ventoux (Vaucluse, France) and with potted saplings - from the same origin - under shaded tunnels in southern France (Avignon, Vaucluse), and north-eastern France (Nancy, Meurthe-et-Moselle). Leaf mass to area ratio and leaf carbon content per unit mass increased, while leaf nitrogen content per unit mass $\left(N_{\mathrm{m}}\right)$ remained constant, with increasing relative irradiance (RI). Maximum carboxylation rate $\left(V_{\mathrm{cmax}}\right)$ and maximum electron transport flux $\left(J_{\max }\right)$ increased with RI and were higher in the natural regeneration than in the potted saplings. These two parameters were higher for the potted saplings in north-eastern France than for those in southern France. Leaf nitrogen allocation to carboxylation $\left(P_{\mathrm{r}}\right)$ or bioenergetics $\left(P_{\mathrm{b}}\right)$ did not vary with RI. $P_{\mathrm{r}}$ and $P_{\mathrm{b}}$ were higher in the natural regeneration than in the potted saplings, whereas $N_{\mathrm{m}}$ was lower in the natural regeneration than in the fertilised potted saplings. Seasonal time course of these parameters in the natural regeneration in Mont-Ventoux, from bud burst to the beginning of summer drought, showed that after the leaf expansion period, leaf composition and photosynthetic parameters remain globally constant.
\end{abstract}

maximum carboxylation rate $\left(V_{\mathrm{cmax}}\right) /$ maximum electron transport flux $\left(J_{\mathrm{max}}\right)$ / nitrogen allocation / relative irradiance / seasonal variability

Résumé - Acclimatation à la lumière et réponse photosynthétique de jeunes plants de hêtre (Fagus sylvatica L.) sous ombrage artificiel ou en conditions naturelles en région méditerranéenne. L'acclimatation du hêtre (Fagus sylvatica L.) à la lumière a été étudiée dans des régénérations naturelles sous couvert de pin noir d'Autriche (Pinus nigra ssp. nigricans) dans le Mont-Ventoux et chez des jeunes plants en pots - de même origine - sous tunnels ombragés dans le sud de la France (Avignon, Vaucluse) et dans le nord-est de la France (Nancy, Meurtheet-Moselle). La masse spécifique foliaire et la teneur en carbone par unité de masse foliaire augmentent avec l'éclairement relatif (RI) alors que la teneur en azote par unité de masse foliaire $\left(N_{\mathrm{m}}\right)$ reste constante. La vitesse maximale de carboxylation $\left(V_{\mathrm{cmax}}\right)$ et le flux maximum d'électrons $\left(J_{\max }\right)$ augmentent avec RI et sont plus élevés dans les régénérations naturelles que chez les plants en pots. Ces deux paramètres sont plus élevés pour les plants en pots du nord-est que ceux du sud de la France. L'allocation de l'azote foliaire aux processus de carboxylation $\left(P_{\mathrm{r}}\right)$ ou bioénergétiques $\left(P_{\mathrm{b}}\right)$ ne varie pas avec RI. $P_{\mathrm{r}}$ et $P_{\mathrm{b}}$ sont plus élevés pour les régénérations naturelles que pour les plants en pots alors que $N_{\mathrm{m}}$ est plus basse pour les régénérations naturelles que pour les plants en pots qui ont été fertilisés. L'évolution saisonnière de ces paramètres, pour les régénérations naturelles du Mont-Ventoux, depuis le débourrement jusqu'au début de la sécheresse estivale montre que, après la phase d'expansion des feuilles, la composition foliaire et les paramètres photosynthétiques restent globalement constants.

vitesse maximale de carboxylation $\left(V_{\mathbf{c m a x}}\right)$ / flux maximum d'électrons $\left(J_{\max }\right)$ / allocation de l'azote / éclairement relatif / variabilité saisonnière

\section{INTRODUCTION}

Beech (Fagus sylvatica L.), a widely distributed European forest tree, is at its French southern limit in medium altitude mountains (between 1000 and 1500 m elevation ) of the Mediterranean region. Because of a high anthropic pressure, it was almost extinct in the Mediterranean region at the end of XIXth century [12]. During the past decades, it has recovered a larger distribution by colonising the understory of pioneer species, such as black pine (Pinus nigra ssp. nigricans) that had been extensively planted in the Mediterranean mountains at the end of XIXth century. The high temperature characterising Mediterranean climate induce a specific situation for beech. The management of this regeneration should take in account this

\footnotetext{
* Corresponding author: ducrey@avignon.inra.fr
} 
specificity in order to maintain its surviving. However little is known about ecophysiology of beeches in such extreme climatic conditions.

Position of species in forest successions is governed by several ecological factors such as shade tolerance [4]. Pioneer species are generally shade intolerant, and display a rapid growth in open ground. Late succession species survive under shading, are rather intolerant to high light, and display a slower growth $[20,35]$. End succession species often need overstory of pioneer and intermediary species for germinating and their initial growth. This protective cover becomes particularly necessary in the severe conditions of Mediterranean climate, where extreme climatic constraints interact with shade tolerance. Mediterranean climate is principally characterised by a higher summer temperature, and, as a consequence, a higher vapour pressure deficit, than those in which beech populations located in north eastern France are found. Acclimation to such an environment should interact with shade tolerance capacity of beech by the way of acclimation of photosynthetic apparatus.

The large light induced plasticity in the morphology of forest species has been frequently described [1, 3, 8, 11, 29]. An important acclimation is the increase of leaf mass to area ratio (LMA) with irradiance [32], that results from an increase of epidermis and parenchyma thickness [2, 3]. The carbon balance is highly modulated by the plasticity of the photosynthetic apparatus [5]. The maximum carboxylation rate $\left(V_{\mathrm{cmax}}\right)$ and the maximum electron transport flux $\left(J_{\max }\right)$ [18] are highly modulated by irradiance as well as leaf nitrogen allocated to carboxylation $\left(P_{\mathrm{r}}\right)$ or bioenergetics $\left(P_{\mathrm{b}}\right)$ [40]. Moreover, leaf nitrogen per unit area $\left(N_{\mathrm{a}}\right)$ depends on leaf nitrogen content per unit dry mass $\left(N_{\mathrm{m}}\right)$ and LMA. So, Niinemets and Tenhunen [40] pointed out the difficulty to separate anatomical adjustment in foliage structure (LMA variation) and biochemical modification in foliar composition ( $N_{\mathrm{m}}$ variation) when studying response to light regime.

Nitrogen versus photosynthetic parameters relationships are often used in functional modelling of forest ecosystems, and variation of these relationships during the growing season is of major interest $[23,52]$. In a general way, $V_{\mathrm{cmax}}$ and $N_{\mathrm{a}}$ remain constant after leaf expansion, unless a summer drought or a high temperature stress occur [13, 24, 53]. Moreover, soil nutrient status, and particularly nitrogen fertilisation, interact with seasonal variation of $N_{\mathrm{a}}$, and needs to be taken in account when studying $V_{\text {cmax }}$ versus $N_{\text {a }}$ relationships [7, 22, 50].

In this study, we focussed on the natural regeneration of beech in the understory of black pine stands, on the slopes of the Mont-Ventoux mountain. We examined the extent of beech acclimation (phenotypic plasticity) to different levels of relative light intensity, as well as under natural conditions than under artificial shading. We also tested if acclimation to Mediterranean climate modify shade response of beech, independently of irradiance differences between north-eastern and southern France. In this aim, potted saplings were studied in two different environmental conditions under shaded tunnels, in southern France (highest temperatures, Avignon, Vaucluse), and north-eastern France (lowest temperatures, Nancy, Meurthe-et-Moselle). Estimations of $V_{\mathrm{cmax}}$ and $J_{\max }$, and of nitrogen allocation to this two parameters $\left(P_{\mathrm{r}}\right.$ and $P_{\mathrm{b}}$, respectively) were related to growth conditions and climatic environment. In order to validate acclimation to Mediterranean climate observed for the potted saplings, to that of saplings growing in less fertilised field conditions, the same parameters were monitored for the natural regeneration. Their seasonal variations were assessed in order to test the stability of the relationships of photosynthesis parameters versus leaf nitrogen content, for a future use in functional tree modelling.

\section{MATERIALS AND METHODS}

\subsection{Plant material}

A demographic study of the variation of natural regeneration in south of France (Mont-Ventoux $5^{\circ} 17^{\prime} \mathrm{E}, 44^{\circ} 10^{\prime} \mathrm{N}$, close to Avignon) in black pine stands with varying species composition and density [10], helped us to select three plots corresponding to different density of cover. Plots of $5000 \mathrm{~m}^{2}$ with similar microclimates and soils were located between 1120 and $1210 \mathrm{~m}$ altitude. Each plot was subdivided in $100 \mathrm{~m}^{2}$ cells. In the centre of each cell, a hemispherical photography was taken at about $1 \mathrm{~m}$ above ground, to estimate the relative irradiance received by the beech leaves in these cells. Hemispherical photographs were taken during summer 2001 when canopy was fully expanded, and data were processed using the Gap Light Analyser (GLA) software [19]. Relative irradiance is an estimation of the mean ratio of photosynthetic active radiation transmitted to seedlings throughout the forest canopy during the May-September period. We selected 37 cells to cover the full range of irradiance conditions (A. Porté, personal communication): 7 between 7 and $15 \%$ of full sunlight, 7 between 15 and $30 \%, 6$ between 30 and $45 \%, 5$ between 45 and $60 \%, 6$ between 60 and $75 \%$, and 6 at about $100 \%$ in zones where black pines were cut. Leaves used for our study were chosen as close as possible (less than $1 \mathrm{~m}$ ) to the point where hemispherical photographs were taken, and at 1 meter above ground level independently of the sapling size and age.

For the study under controlled conditions, seeds of beech were sampled in the vicinity of these plots, during autumn 1999. During 2000, seeds germinated and young seedlings grew in $400-\mathrm{cm}^{3}$ pots containing a mixture of peat and pine bark, under five tunnels with different shading conditions (Tab. I) in the south of France (Avignon $4^{\circ} 50^{\prime} \mathrm{E}$, $43^{\circ} 57^{\prime} \mathrm{N}$ ). Shade was provided with neutral shade nets, which are assumed to not modify spectral light composition. During March 2001, they were transplanted into 3-L pots, with the same substrate. Half of the plants were kept in southern France and remained in the same tunnels (except of plants the most lighted placed in shadier conditions, to prevent a too high mortality). The second half was transferred to tunnels in north-eastern France (Nancy $6^{\circ} 11^{\prime} \mathrm{E}, 48^{\circ} 41^{\prime} \mathrm{N}$ ), in order to grow them under less constraining environments (Tab. II). The different irradiance levels are reported in Table I. Plants were regularly watered, and fertilised each week with liquid fertiliser (N/P/K: 9/9/9) diluted to $1 \%$.

Microclimate for the potted plants during growth (Tab. II) and for the natural regenerations during the experiment (Tab. III), were measured by meteorological stations in open areas close to the experimental plots.

\subsection{Leaf composition}

Leaf area was measured using a DIAS system (Delta-T Device, Cambridge, England). Thereafter leaves were dried at $65^{\circ} \mathrm{C}$ for $48 \mathrm{~h}$, and weighted to calculate leaf mass to area ratio (LMA). Carbon and nitrogen content were measured on all leaves used for gas exchange, using a Carlo Erba elementary analyser, after milling with a ball mill (Retsck MM 200). 
Table I. Relative irradiance conditions (in per cent of global irradiance) during growth of potted saplings. Numbers in parenthesis show relative irradiance in north-eastern France (Nancy) in per cent of global irradiance in southern France (Avignon): mean global irradiance in northeastern France meteorological station was $81.6 \%$ of southern France meteorological station during the study period.

\begin{tabular}{lcccccc}
\hline Year & Location & Block 0 & Block 1 & Block 2 & Block 3 & Block 4 \\
\hline 2000 & Southern France & 85.0 & 54.9 & 34.2 & 20.2 & 13.9 \\
2001 & Southern France & 43.3 & 54.9 & 34.2 & 20.2 & 13.9 \\
2001 & North-eastern France & $100(81.6)$ & $39(31.8)$ & $3(2.5)$ & $23(18.8)$ & $8(6.5)$ \\
\hline
\end{tabular}

Table II. Climatic conditions for the potted plants during growth (data from the nearest meteorological station at Avignon, southern France, and Nancy, north-eastern France).

\begin{tabular}{|c|c|c|c|c|c|c|c|c|}
\hline & \multicolumn{4}{|c|}{ Southern France (2001) } & \multicolumn{4}{|c|}{ North-eastern France (2001) } \\
\hline & April & May & June & July & April & May & June & July \\
\hline Minimum temperature $\left({ }^{\circ} \mathrm{C}\right)$ & 6.9 & 13.0 & 15.2 & 17.3 & 3.3 & 7.2 & 9.6 & 12.3 \\
\hline Maximum temperature $\left({ }^{\circ} \mathrm{C}\right)$ & 18.3 & 24.3 & 27.9 & 30.4 & 13.3 & 17.4 & 20.5 & 23.5 \\
\hline $\begin{array}{l}\text { Means of daily global } \\
\text { radiation }\left(\mathrm{MJ} \mathrm{m}^{-2}\right)\end{array}$ & 20.35 & 22.51 & 28.28 & 25.96 & 14.04 & 21.42 & 21.82 & 21.97 \\
\hline
\end{tabular}

Table III. Climatic conditions for natural regeneration at Mont-Ventoux (southern France), and predawn leaf water potential of plants during photosynthesis measurements in 2002.

\begin{tabular}{|c|c|c|c|c|c|}
\hline & $\begin{array}{c}\text { Series } 1 \\
\text { May } 21-28\end{array}$ & $\begin{array}{c}\text { Series } 2 \\
\text { June } 3-13\end{array}$ & $\begin{array}{c}\text { Series } 3 \\
\text { June } 17-26\end{array}$ & $\begin{array}{c}\text { Series } 4 \\
\text { July } 2-10\end{array}$ & $\begin{array}{c}\text { Series } 5 \\
\text { July } 15-23\end{array}$ \\
\hline Minimum temperature $\left({ }^{\circ} \mathrm{C}\right)$ & $\begin{array}{c}6.4 \\
(2.5-10.0)\end{array}$ & $\begin{array}{c}8.5 \\
(5.2-13.7)\end{array}$ & $\begin{array}{c}16.4 \\
(13.7-19.2)\end{array}$ & $\begin{array}{c}11.0 \\
(7.2-14.1)\end{array}$ & $\begin{array}{c}13.7 \\
(10.6-17.5)\end{array}$ \\
\hline Maximum temperature $\left({ }^{\circ} \mathrm{C}\right)$ & $\begin{array}{c}15.7 \\
(12.4-18.6)\end{array}$ & $\begin{array}{c}16.8 \\
(11.1-24.3)\end{array}$ & $\begin{array}{c}27.0 \\
(25.3-29.3)\end{array}$ & $\begin{array}{c}22.4 \\
(18.3-26.1)\end{array}$ & $\begin{array}{c}23.7 \\
(18.0-28.8)\end{array}$ \\
\hline $\begin{array}{l}\text { Global radiation } \\
\left(\mathrm{MJ} \mathrm{m}^{-2} \mathrm{Day}^{-1}\right)\end{array}$ & $\begin{array}{c}22.6 \\
(6.4-30.4)\end{array}$ & $\begin{array}{c}21.6 \\
(8.2-29.6)\end{array}$ & $\begin{array}{c}27.9 \\
(25.9-28.9)\end{array}$ & 25.5 & $\begin{array}{c}25.0 \\
(17.8-29.0)\end{array}$ \\
\hline $\begin{array}{l}\text { Penman's ETP } \\
\left(\mathrm{mm} \mathrm{Day}^{-1}\right)\end{array}$ & $\begin{array}{c}3.2 \\
(1.4-4.0)\end{array}$ & $\begin{array}{c}3.3 \\
(1.4-4.8)\end{array}$ & $\begin{array}{c}5.1 \\
(4.6-5.5)\end{array}$ & $\begin{array}{c}4.2 \\
(3.4-5.7)\end{array}$ & $\begin{array}{c}4.3 \\
(2.9-5.0)\end{array}$ \\
\hline $\begin{array}{l}\text { Predawn leaf water potential } \\
\text { (MPa) }\end{array}$ & $\begin{array}{r}-0.174 \\
\pm 0.014\end{array}$ & $\begin{array}{r}-0.147 \\
\pm 0.015\end{array}$ & $\begin{array}{r}-0.238 \\
\pm 0.019\end{array}$ & $\begin{array}{r}-0.284 \\
\pm 0.022\end{array}$ & $\begin{array}{r}-0.821 \\
\pm 0.074\end{array}$ \\
\hline
\end{tabular}

In parenthesis: extreme values. For predawn leaf water potential: mean \pm standard error of the mean.

\section{3. $\mathrm{A}(\mathrm{Ci})$ curves, and photosynthesis parameters}

In order to estimate the photosynthetic capacity of leaves, we calculated maximum carboxylation rate $\left(V_{\mathrm{cmax}}\right)$ and maximum electron transport flux $\left(J_{\max }\right)$, by applying the model of Farquhar et al. [18] on net $\mathrm{CO}_{2}$ assimilation versus internal $\mathrm{CO}_{2}$ concentration $\left(C_{\mathrm{i}}\right)$ curves. Net assimilation measurements were done using a portable gas exchange measurement chamber, temperature, $\mathrm{CO}_{2}$, light, and air humidity regulated (LI-6400, Li-Cor, Lincoln, Nebraska), using the protocol described by Dreyer et al. [9]. Temperature and humidity were maintained constant, with a photon flux density of $1500 \mu \mathrm{mol}$ $\mathrm{m}^{-2} \mathrm{~s}^{-1}$. After 5-min exposition at $250 \mathrm{ppm} \mathrm{CO}_{2}$ to obtain maximum stomatal opening, $\mathrm{CO}_{2}$ concentration was set at $2000 \mathrm{ppm}$ and 8 to 12 measurements were made at decreasing $\mathrm{CO}_{2}$ concentration until $50 \mathrm{ppm}$. For the application of Farquhar et al. model [18], modified by Harley and Tenhunen [25], we used a non-linear adjustment procedure and numeric values from Le Roux et al. [30], Dreyer et al. [9] and Warren et al. [51]. A standardisation of data for $25^{\circ} \mathrm{C}$ was done in order to compensate for fluctuations of temperature among measurement, using numeric data from response curves of $V_{\mathrm{cmax}}$ and $J_{\max }$ versus temperature as described by Dreyer et al. [9]. Briefly, we used the following numeric values for the main parameters of the model at $25^{\circ} \mathrm{C}$ : apparent quantum yield $\alpha=0.24$ mol electrons $\mathrm{mol}^{-1}$ photons; affinity of Rubisco for $\mathrm{CO}_{2} \mathrm{~K}_{\mathrm{c}}=40 \mathrm{~Pa}$; affinity of Rubisco for $\mathrm{O}_{2}$ $\mathrm{K}_{\mathrm{o}}=25 \mathrm{kPa}$; specificity factor of Rubisco $\tau=2710$. Temperature dependency calculations for these parameters imply activation energy factors: for $\mathrm{K}_{\mathrm{c}}, \Delta \mathrm{H}_{\mathrm{a}(\mathrm{Kc})}=70 \mathrm{~kJ} \mathrm{~mol}^{-1}$; for $\mathrm{K}_{\mathrm{O}}, \Delta \mathrm{H}_{\mathrm{a}(\mathrm{Ko})}=15 \mathrm{~kJ} \mathrm{~mol}^{-1}$, and for $\tau, \Delta \mathrm{H}_{\mathrm{a}(\mathrm{t})}=-29 \mathrm{~kJ} \mathrm{~mol}^{-1}$.

We also calculated fractions of nitrogen allocated to carboxylation $\left(P_{\mathrm{r}}\right)$ and electron transport $\left(P_{\mathrm{b}}\right)$ as described by Niinemets and Tenhunen [40].

\subsection{Measurement timing and micro-environmental conditions}

\subsubsection{For the potted saplings growing under controlled conditions in southern France}

Measurements were made between July 3 and August 3, 2001. In order to compensate for potential physiological differences during this period, plants from all the different tunnels were measured each day. 
Table IV. Slopes of linear regressions between relative irradiance and leaf mass-to-area ratio (LMA), nitrogen content per unit leaf area $\left(N_{\mathrm{a}}\right)$ or per unit dry mass $\left(N_{\mathrm{m}}\right)$.

\begin{tabular}{|c|c|c|c|c|c|}
\hline & & $n$ & $\mathrm{LMA}=\mathrm{f}(\mathrm{RI})$ & $N_{\mathrm{a}}=\mathrm{f}(\mathrm{RI})$ & $N_{\mathrm{m}}=\mathrm{f}(\mathrm{RI})$ \\
\hline \multicolumn{2}{|c|}{$\begin{array}{l}\text { Potted saplings in north-east of France } \\
2001\end{array}$} & 50 & $0.385\left(0.906^{* * *}\right)$ & $0.0088(0.750 * * *)$ & $-0.0065(-0.453 * * *)$ \\
\hline \multirow{6}{*}{$\begin{array}{l}\text { Natural } \\
\text { regeneration } \\
2002\end{array}$} & Series 1 & 31 & $0.383(0.667 * * *)$ & $0.0121(0.810 * * *)$ & $0.0053\left(\sim 0^{\mathrm{NS}}\right)$ \\
\hline & Series 2 & 36 & $0.595(0.904 * * *)$ & $0.0154(0.901 * * *)$ & $0.0023\left(\sim 0^{\mathrm{NS}}\right)$ \\
\hline & Series 3 & 35 & $0.578(0.917 * * *)$ & $0.0159(0.897 * * *)$ & $0.0041(0.360 *)$ \\
\hline & Series 4 & 36 & $0.609(0.888 * * *)$ & $0.0150(0.861 * * *)$ & $0.0021\left(\sim 0^{\mathrm{NS}}\right)$ \\
\hline & Series 5 & 36 & $0.543(0.868 * * *)$ & $0.0133(0.843 * * *)$ & $0.0025\left(\sim 0^{\mathrm{NS}}\right)$ \\
\hline & Total & 174 & $0.590(0.852 * * *)$ & $0.0150(0.870 * * *)$ & $0.0023(0.178 *)$ \\
\hline
\end{tabular}

In parenthesis are shown Pearson's correlation coefficients and significance levels: $1 \%\left(^{* * *}\right), 1 \%(* *), 5 \%(*)$ or non significant (NS); n: number of observations.

Plants were watered and brought each morning to the laboratory, into a constant microclimatic environment. The LI-6400 chamber conditions were: air temperature: $25.9{ }^{\circ} \mathrm{C}$, from 25.5 to $26.6{ }^{\circ} \mathrm{C}$, leaf temperature: $28.0{ }^{\circ} \mathrm{C}$, from 26.0 to $29.7^{\circ} \mathrm{C}$, and relative air humidity: $69.7 \%$, from 62.7 to $77.5 \%$.

\subsubsection{For the potted saplings growing under controlled conditions in north-eastern France}

We transferred the plants growing in north-eastern France at the beginning of August 2001 into a shaded and air-conditioned greenhouse. Measurements were done for two weeks between August 13 and August 30, 2001, as described above. Microclimatic conditions in the LI-6400 chamber were: air temperature: $26.1^{\circ} \mathrm{C}$, from 25.7 to $26.5^{\circ} \mathrm{C}$, leaf temperature: $28.3^{\circ} \mathrm{C}$, from 27.1 to $29.1^{\circ} \mathrm{C}$, and air relative humidity: $69.6 \%$, from 62.7 to $73.4 \%$.

\subsubsection{For the natural regeneration}

$\mathrm{A}(\mathrm{Ci})$ curves of the natural regeneration were done at five different dates between May 21 and July 23, 2002. Whereas microclimatic conditions in the LI-6400 chamber were programmed at $20{ }^{\circ} \mathrm{C}$ and $50 \%$ relative humidity (except the first series: $60 \%$ ), real values were different, due to variations of sunlight in the vicinity of the beech regeneration: mean leaf temperature was between 19.9 and $22.4{ }^{\circ} \mathrm{C}$, (extremes values: 17.5 and $29.8^{\circ} \mathrm{C}$ ), and mean relative humidity was between 50.4 and $59.6 \%$ (extremes values: 35.3 and $64.3 \%$ ).

\subsection{Statistical analysis}

$V_{\text {cmax }}$ and $J_{\max }$ were estimated from the A(Ci) curves using a SAS program (SAS Institute Inc., Cary, NC, USA) based on non-linear regression procedure of SAS, with optimisation of the repartition of experimental points between the two segments of the $\mathrm{A}(\mathrm{Ci})$ curves as described by Dreyer et al. [9]. Statistical relations between variables were studied using the correlation procedure and linear regression procedure of SAS. Effects and interactions of experimental factors were tested with a linear model. When significant differences were found among a factor $(p<0.05)$, mean comparisons were made using TukeyKramer test. For the natural regeneration, time evolution of traits was tested with a linear model with light as co-variate in order to cancel the effect of light environment.

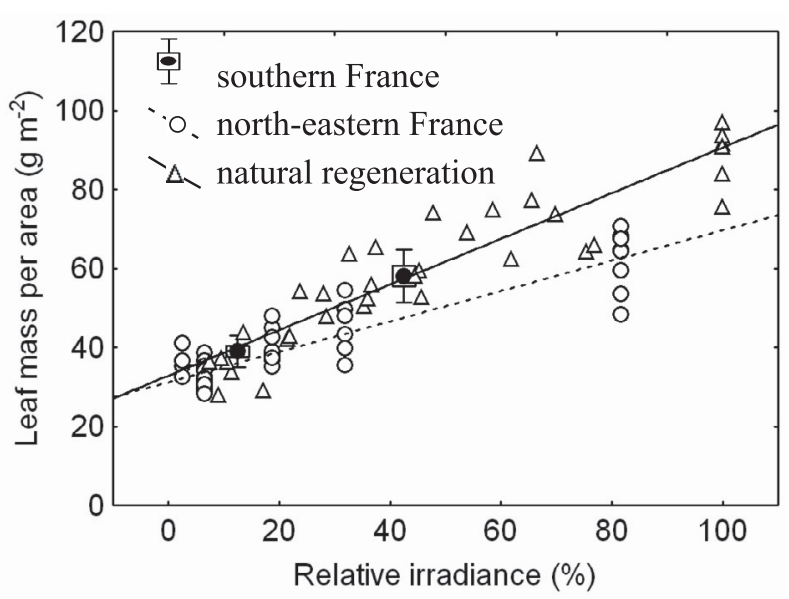

Figure 1. Leaf mass-to-area ratio (LMA) versus relative irradiance (in per cent of global irradiance in southern France, Avignon) for the potted saplings in north-eastern France (plots and linear regression) and southern France (mean, standard deviation and confidence interval of the mean), and for the natural regeneration (plots and linear regression). Only the 3 rd series is shown, corresponding to mature leaves.

\section{RESULTS}

\subsection{Leaf composition and relative irradiance}

In all experimental situations tight linear positive relationships were detected between leaf mass to area ratio (LMA) and relative irradiance (RI, in per cent of the absolute irradiance recorded at Avignon, south of France) (Fig. 1). Values for the potted saplings in southern France were close to the linear regression fitted for the natural regeneration. However, the regression line for the potted saplings in north-eastern France was clearly under the values of the potted saplings in southern France, and the slope of the linear regression was lower than the slope for the natural regeneration (Tab. IV).

Leaf nitrogen content per unit mass $\left(N_{\mathrm{m}}\right)$ was lower in the natural regeneration (mean $=2.5 \%$ ) than in the potted saplings (means between 3 and $3.5 \%$ ). $N_{\mathrm{m}}$ remained constant with RI, 

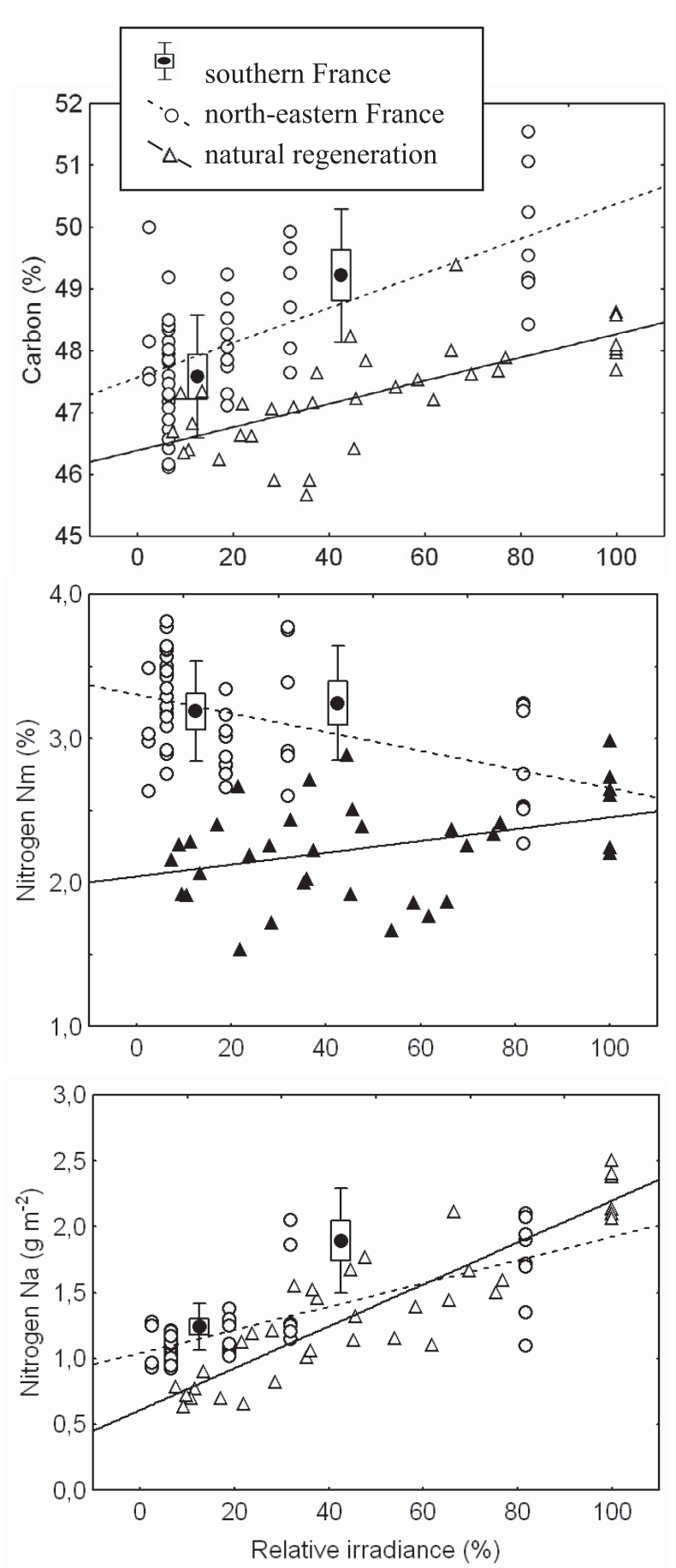

Figure 2. Carbon contents in per cent of dry mass, nitrogen contents in per cent of dry mass $\left(N_{\mathrm{m}}\right)$ and nitrogen content by unit leaf area $\left(N_{\mathrm{a}}\right)$ versus relative irradiance (in per cent of global irradiance in southern France, Avignon) for the potted saplings in north-eastern France (plots and linear regression) and in southern France (mean, standard deviation and confidence interval of the mean), and for the natural regeneration (plots and linear regression). Only the 3rd series is shown, corresponding to mature leaves.

in the potted saplings in southern France and in the natural regeneration (Fig. 2). It significantly decreased with RI for the potted saplings in north-eastern France (Tab. IV). Nitrogen content by unit leaf area $\left(N_{\mathrm{a}}\right)$ significantly increased with RI (Fig. 2) due to increased LMA, for all experimental situations. As the slope of the linear regression between LMA and RI was significantly higher for the natural regeneration (which had values similar to that of the potted saplings in southern France) than for the saplings in north-eastern France (Fig. 1), we found no significant differences of $N_{\mathrm{a}}$ between the potted saplings in north-eastern France and the saplings in the natural regeneration, whereas a lower $N_{\mathrm{m}}$ for the saplings of the natural regeneration. However $N_{\mathrm{a}}$ of the potted saplings in southern France was always higher than those of the saplings in natural regeneration or north-eastern France. Carbon content by unit mass increased significantly with RI (Fig. 2), in all experimental situations.

\subsection{Photosynthetic capacity and nitrogen allocation}

The maximum carboxylation rate $\left(V_{\mathrm{cmax}}\right)$ and the maximum electron flux $\left(J_{\max }\right)$ linearly increased with irradiance (Fig. 3). These two parameters were strongly inter-correlated (Tab. V). $V_{\text {cmax }}$ and $J_{\max }$ were significantly lower for the potted saplings than for the natural regeneration, and no differences were found between the potted saplings in north-eastern and in southern France.

Leaf nitrogen fractions allocated to carboxylation $\left(P_{\mathrm{r}}\right)$ and electron transport $\left(P_{\mathrm{b}}\right)$, remained constant (Fig. 4$)$ in all experimental conditions (slopes not significantly different from zero). Means of $P_{\mathrm{r}}$ and $P_{\mathrm{b}}$ were $32.6 \%$ and $6.6 \%$, for the natural regeneration, $13.5 \%$ and $2.6 \%$ for the potted saplings in northeastern France, and $10 \%$ and $2.1 \%$ for the potted saplings in southern France respectively. The differences between the potted saplings and the natural regeneration were highly significant.

\subsection{Temporal pattern of photosynthetic parameters in the natural regeneration}

Climatic conditions differed from the 1 st to the 5 th gas exchange measurement series (Tab. III). Temperature and global radiation increased from May to July, with a maximum in mid-June. Humidity was also lower during this period, resulting in a higher potential evapotranspiration. The period from June 13 to June 27 was the hottest of summer 2002 with mean maximum temperature of $27.0^{\circ} \mathrm{C}$ in Mont-Ventoux and $32.7^{\circ} \mathrm{C}$ in Avignon. The summer drought period, which resulted in decreasing predawn water potential of the young beeches, only began from mid-July.

LMA significantly increased from the first to the second series, and remained stable during the remaining season (Tab. VI). Leaf carbon content significantly increased from mid-May to mid-July, and with a proportionally lower value for the first measurement series. Nitrogen content $\left(N_{\mathrm{m}}\right)$ was higher in the first series, then decreased for the remaining measurements. In result of $N_{\mathrm{m}}$ and LMA evolution, $N_{\mathrm{a}}$ did not vary during the seasonal time course. The photosynthetic parameters $V_{\text {cmax }}$ and $J_{\text {max }}$, standardised at $25^{\circ} \mathrm{C}$, increased from the first to the third series and then decreased (Tab. VI). Leaf nitrogen fractions allocated to carboxylation $\left(P_{\mathrm{r}}\right)$ and electron transport $\left(P_{\mathrm{b}}\right)$, standardised at $25^{\circ} \mathrm{C}$, (Fig. 4), followed the same variations as $V_{\text {cmax }}$ and $J_{\text {max }}$. 

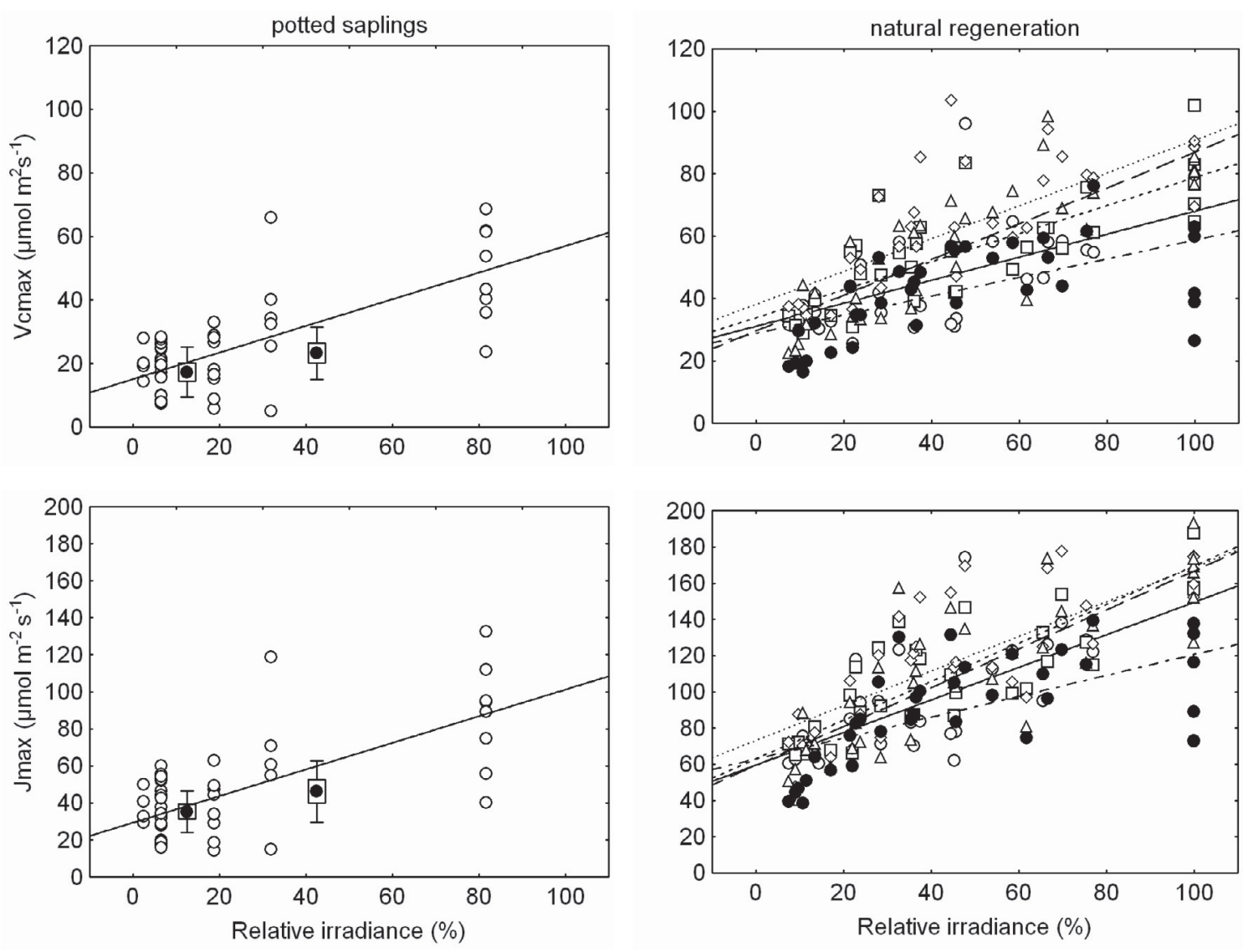

Potted saplings:

호 southern France

$\because$. north-eastern France

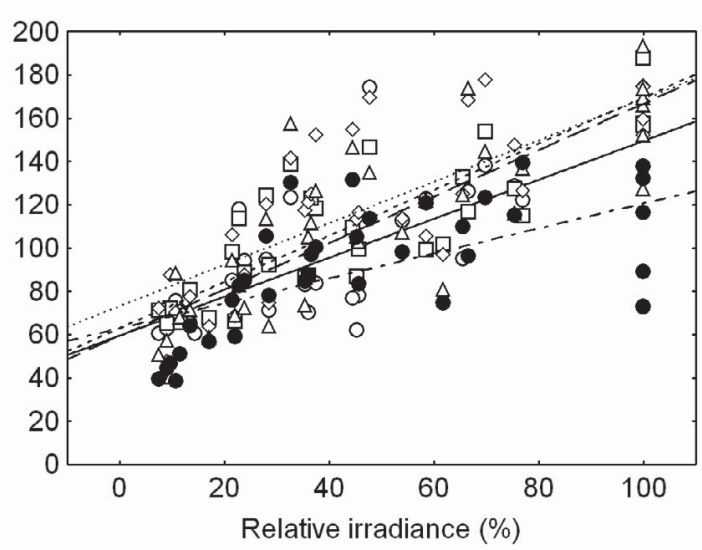

Natural regeneration:

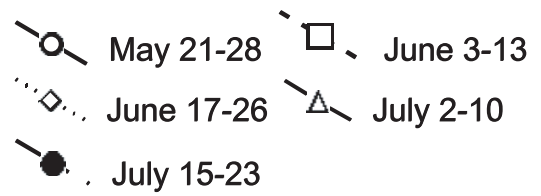

Figure 3. Relationships between maximum carboxylation rate $\left(V_{\mathrm{cmax}}, \mu \mathrm{mol} \mathrm{m} \mathrm{m}^{-2} \mathrm{~s}^{-1}\right)$ or maximum electron transport flux $\left(J_{\max }, \mu\right.$ mol m$\left.{ }^{-2} \mathrm{~s}^{-1}\right)$ standardised values at $25^{\circ} \mathrm{C}$, and relative irradiance (in per cent of global irradiance in southern France, Avignon) for the potted saplings in north-eastern France (plots and linear regression) and southern France (mean, standard deviation and confidence interval of the mean), and for the saplings of natural regeneration (plots and linear regression) at 5 different times during the growth season.

Table V. Slopes of linear relations between $V_{\mathrm{cmax}}, J_{\max }$ and RI.

\begin{tabular}{|c|c|c|c|c|c|}
\hline & & $n$ & $V_{\mathrm{cmax}}=\mathrm{f}(\mathrm{RI})$ & $J_{\max }=\mathrm{f}(\mathrm{RI})$ & $V_{\text {cmax }}=\mathrm{f}\left(J_{\max }\right)$ \\
\hline $\begin{array}{l}\text { Potted saplings in north-east } \\
\text { of France } 2001\end{array}$ & & 50 & $0.419(0.714 * * *)$ & $0.719(0.693 * * *)$ & $0.550(0.972 * * *)$ \\
\hline \multirow{6}{*}{$\begin{array}{l}\text { Natural } \\
\text { regeneration } \\
2002\end{array}$} & Series 1 & 31 & $0.369(0.532 * *)$ & $0.899\left(0.663^{* * *}\right)$ & $0.491(0.960 * * *)$ \\
\hline & Series 2 & 34 & $0.449\left(0.775^{* * *}\right)$ & $1.065\left(0.856^{* * *}\right)$ & $0.418(0.898 * * *)$ \\
\hline & Series 3 & 35 & $0.527\left(0.769^{* * *}\right)$ & $0.957\left(0.785^{* * *}\right)$ & $0.521\left(0.926^{* * *}\right)$ \\
\hline & Series 4 & 36 & $0.573(0.829 * * *)$ & $1.074(0.819 * * *)$ & $0.480(0.911 * * *)$ \\
\hline & Series 5 & 36 & $0.299(0.609 * * *)$ & $0.577\left(0.608^{* * *}\right)$ & $0.468(0.904 * * *)$ \\
\hline & Total & 172 & $0.464\left(0.688^{* * *}\right)$ & $0.924\left(0.736^{* * *}\right)$ & $0.494(0.920 * * *)$ \\
\hline
\end{tabular}

In parenthesis are shown Pearson's correlation coefficients and significance levels: $1 \%{ }^{(* * *)}, 1 \%(* *), 5 \%(*)$ or non significant (NS); n: number of observations. 

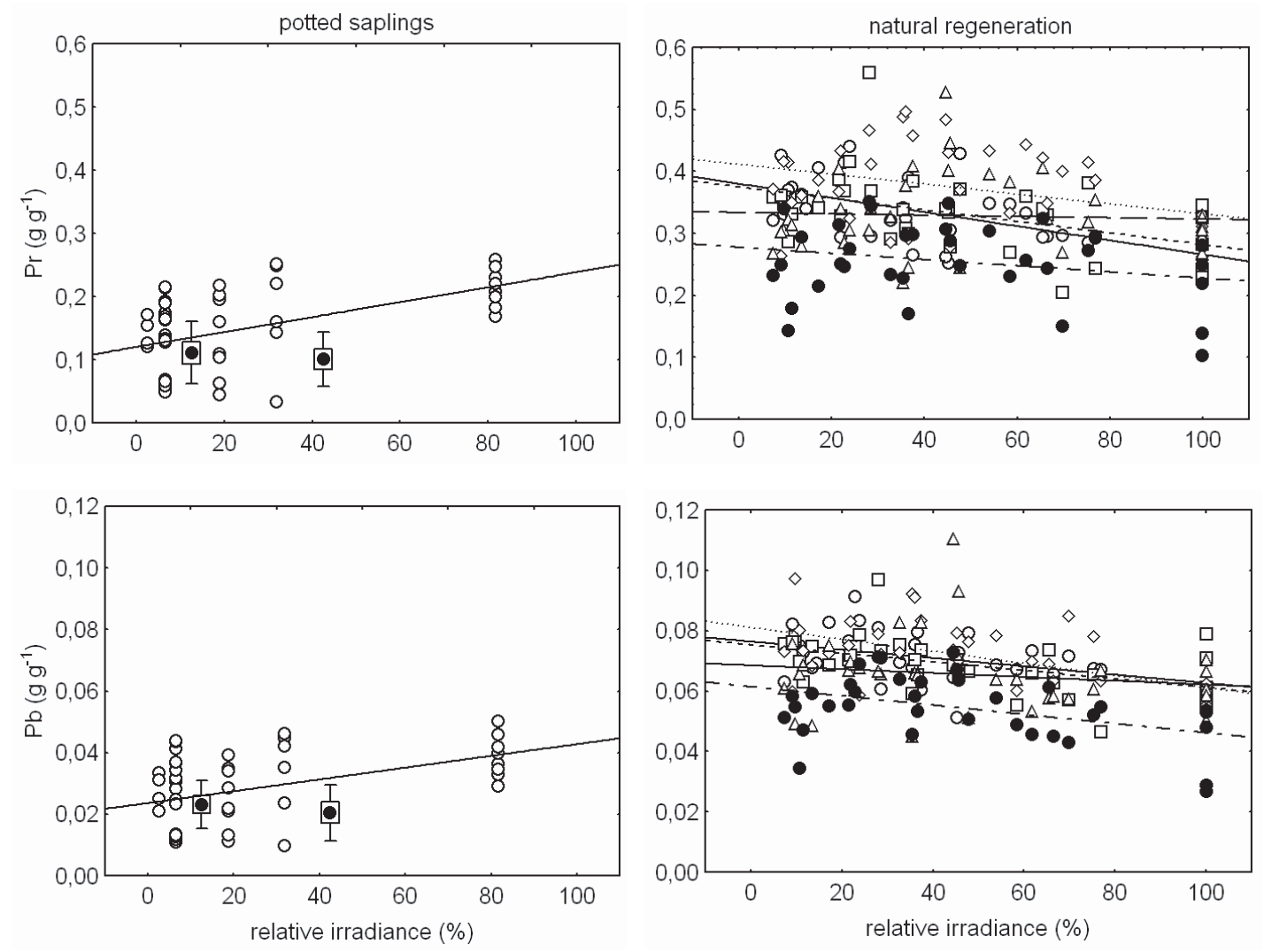

Potted saplings:

Natural regeneration:

南 southern France

○. north-eastern France

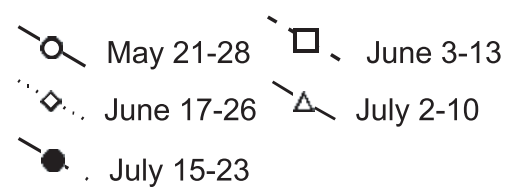

Figure 4. Leaf nitrogen fraction allocated to carboxylation $\left(P_{\mathrm{r}}\right)$ and electron transport $\left(P_{\mathrm{b}}\right)$ (standardised values at $\left.25^{\circ} \mathrm{C}\right)$, versus growth relative irradiance (in per cent of global irradiance in southern France, Avignon) for the potted saplings in north-eastern France (plots and linear regression) and southern France (mean, standard deviation and confidence interval of the mean), and for the saplings of natural regeneration (plots and linear regression) at 5 different times during the growth season.

Table VI. Time course of leaf structure and photosynthetic parameters from May to July 2002 in natural regeneration.

\begin{tabular}{|c|c|c|c|c|c|c|}
\hline & $\begin{array}{c}\text { Series } 1 \\
\text { May 21-28 }\end{array}$ & $\begin{array}{r}\text { Series } 2 \\
\text { June } 3-13\end{array}$ & & $\begin{array}{c}\text { Series } 3 \\
\text { June } 17-26\end{array}$ & $\begin{array}{c}\text { Series } 4 \\
\text { July } 2-10\end{array}$ & $\begin{array}{c}\text { Series } 5 \\
\text { July } 15-23\end{array}$ \\
\hline Leaf mass to area ratio $\left(\mathrm{g} \mathrm{m}^{-2}\right)$ & 41.00 & 54.68 & $\mathrm{a}$ & 55.02 & 57.34 & 58.71 \\
\hline Carbon (\% dry weight) & 46.25 & 46.86 & $\mathrm{~b}$ & 47.12 & 46.98 & 47.39 \\
\hline Nitrogen (\% dry weight) & 2.562 & 2.187 & $\mathrm{~b}$ & 2.171 & 2.134 & 2.125 \\
\hline$V_{\text {cmax }}\left(\mu \mathrm{mol} \mathrm{m}{ }^{-2} \mathrm{~s}^{-1}\right)$ & 44.54 & 50.22 & $\mathrm{bc}$ & 59.52 & 51.96 & 41.91 \\
\hline$J_{\max }\left(\mu \mathrm{mol} \mathrm{m}{ }^{-2} \mathrm{~s}^{-1}\right)$ & 92.37 & 100.5 & $a b$ & 110.9 & 100.0 & 87.83 \\
\hline
\end{tabular}

For all parameters, different letters show significant differences with mean comparison test of Tukey-Kramer.

\section{DISCUSSION}

\subsection{Acclimation to relative irradiance}

In a large range of forest tree species, RI (relative irradiance) and leaf mass-to-area ratio (LMA) are tightly correlated [1, 17,
$28,38,44]$, as are RI and nitrogen content on a leaf area basis $\left(N_{\mathrm{a}}\right)[6,21,31,46]$. Our observations are similar to published results usually observed for beech [2, 3, 32].

The observed increase of leaf carbon content with RI in all experiment conditions was a surprise, and has never been 
reported before (Fig. 2). For a vertical gradient within adult tree, Jayasekera and Schleser [26] and Niinemets [37] found no correlation between total carbon content and growth irradiance. However, Niinemets [37] found positive relationships when correlating RI with structural carbohydrates. The correlation we found could be due to an increase of the proportion of structural carbohydrates, particularly lignin [39] in light acclimated leaves, resulting in a higher tissue density.

$J_{\max }$ and $V_{\text {cmax }}$ increased with RI. Our results were close to those found for beech in similar conditions by other authors [14, 34]. We observed no significant variations of $P_{\mathrm{r}}$ and $P_{\mathrm{b}}$ versus RI. This was conform to results currently found by Niinemets et al. [41], and Le Roux et al. [31], whereas Grassi and Bagnaresi [21] found a positive correlation with irradiance for Picea abies. However the model of Farquhar et al. [18] could under-estimates $V_{\text {cmax }}$ because it does not include internal resistance of the mesophyll. For example Piel et al. [42] showed for walnut that this under-estimating is higher for sun leaves than for shade leaves, due to the higher density of sun leaves. So, in our case, the slope of the relationships of $V_{\text {cmax }}$ versus $\mathrm{RI}$ is probably higher because the range of mesophyll conductance for beech [14] is close to that for walnut. In result, $P_{\mathrm{r}}$ could be higher for sun leaves than for shade leaves.

We observed singular behaviour for saplings growing in north-eastern France under 2.5\% RI. LMA and carbon content were higher than predicted values from linear regressions. As a consequence, $V_{\text {cmax }}$ and $J_{\text {cmax }}$ were also higher than predicted values. This should be due to light regime of the previous year (Tab. I): light regime in 2001 was as close as possible of light regime in 2000, except for the saplings from block 2 which were submitted to $34.2 \%$ of RI in 2000 and $2.5 \%$ of RI in 2001. This effect of previous year light regime is often observed when leaf ontogeny and particularly bud formation occur under light conditions different than during leaf expansion [47, 48].

\subsection{Temporal pattern of photosynthetic parameters in the natural regeneration}

LMA highly increased between the two first series and then remained constant. This phenomenon is often observed at the beginning of the season for different species, such as beech [15, 26] or oaks [52]. Leaves first begin to expand, then grow in thickness and progressively heavier structures increase biomass by unit leaf area [45]. Consequently, we observed a slight increase in carbon content by unit mass. The high initial nitrogen content of leaves $\left(N_{\mathrm{m}}\right)$ could be considered as an investment in order to permit an efficient photosynthesis in a situation were leaves are not yet completely developed whereas biochemical functions are operating [45]. After that, the decrease of $N_{\mathrm{m}}$ during time could be attribute to a dilution effect due the increase of carbon content.

$V_{\text {cmax }}$ and $J_{\max }$ as well as $P_{\mathrm{r}}$ and $P_{\mathrm{b}}$ followed air temperature and global irradiance as seen in Table VI. The lower values of these parameters for the first series could be due to leaf maturating whereas the decrease for the fifth series could result of the beginning of edaphic water stress. Under similar soil drought (predawn water potential close to $-0.8 \mathrm{MPa}$ ), Grassi et al. [23] found a $20 \%$ decrease in $V_{\text {cmax }}$ for ash and oak. For the three other series, global irradiance as well as temperature could induced an acclimation of the photosynthetic apparatus [24, $33]$, however no data are available to discuss this phenomenon.

\subsection{Differences between the potted saplings in north-eastern and in southern France}

LMA versus RI relationships were different for the potted saplings in north-eastern France and for those in southern France despite of the fact that RI was expressed on the same global irradiance values. Lower values for the potted saplings in north-eastern France should be attributed to the lower temperature in north-eastern than in southern France (Tab. II). This confirms the hypothesis that the plasticity of beech to light environment is modulated by climatic parameters. However $J_{\max }$ and $V_{\text {cmax }}$ were not significantly different between the potted saplings in north-eastern and in southern France. So variation in LMA did not affect photosynthetic capacities. The highest quantity of matter per unit leaf area for the saplings in southern France should provide highest energetic cost not counterbalanced by higher assimilation capacities. The higher energetic cost could have induced a slower growth rate in saplings maintained under Mediterranean climate. We observed that, but we have no experimental data to confirm this hypothesis. The highest LMA in the hottest conditions should provide a protection against a too high increase of leaf temperature, the sun leaves would more need this protection because of the additional warming due to direct irradiation. Niinemets and Tenhunen [40] found that photosynthetic capacity is mostly governed by LMA than by biochemical modification for a less shade tolerant species (Acer saccharum). In our case of a shade tolerant species, nitrogen allocation to photosynthesis apparatus could be limited as suggested by Reich et al. [43] resulting in no higher photosynthesis capacity despite the higher LMA of the potted saplings in southern than those in north-eastern France.

\subsection{Differences between the potted saplings and the natural regeneration}

$N_{\mathrm{m}}$ did not vary with RI, therefore $N_{\mathrm{a}}$ followed RI and LMA. Similar results were found in beech by Jayasekera and Schleser [26] and Meir et al. [34]. Significant differences found between the potted saplings and the natural regeneration could be attributed to mineral fertilisation which would increased the total nitrogen content of the potted saplings, independently of RI [27]. On one hand $V_{\mathrm{cmax}}$ and $J_{\max }$ values, standardised at $25^{\circ} \mathrm{C}$ and at same irradiance, were lower for the potted saplings than for the natural regeneration, and on the other hand, leaf nitrogen content was higher for the potted saplings. Therefore fertilisation of the potted saplings increased leaf nitrogen content $\left(N_{\mathrm{m}}\right)$ without a positive effect on $V_{\mathrm{cmax}}$ and $J_{\max }$. In result, leaf nitrogen fraction allocated to the different processes of photosynthesis was 3 times higher in the natural regeneration than in the potted saplings. Clearwater and Meinzer [7] found a positive effect of nitrogen fertilisation of Eucalyptus grandis on $J_{\max }$ (and not on $V_{\mathrm{cmax}}$ ), when Grassi et al. [22] on Eucalyptus grandis and Walcroft et al. [49] on peach tree found a positive effect both on $V_{\text {cmax }}$ and $J_{\max }$.

Nitrogen of the potted saplings could be stored as soluble proteins [36]. These proteins are dominated by those of the photosynthetic apparatus [16], which could be inactive resulting in 
low $V_{\text {cmax }}$ and $J_{\max }$ variation, whereas a high nitrogen content in the potted saplings. Warren et al. [51] showed that the proportion of Rubisco photosynthetically inactive in Pinus sylvestris increases with increasing leaf nitrogen content. However reasons of this storage are difficult to understand. In fact, the investment in photosynthesis is very important for the unfertilised saplings in the natural regeneration compared to that of the potted saplings in southern France in similar climatic conditions. Reich et al. [43] suggested that nitrogen could be allocated to other mechanisms in order to resist to different stresses. This would be a characteristic of plants with a slow growth (shade-tolerant) which do not need a full investment in photosynthesis. Measurements of Rubisco content should be necessary to confirm this different hypothesis.

Another hypothesis of low rates of photosynthesis of the potted saplings is that they were grown in pots which were too small. Growth in small pots leads to a reduction of root growth, carbohydrate demand and an end-product inhibition of photosynthesis. This could explain their low rates of photosynthesis per unit $\mathrm{N}$, and why they might be storing nitrogen.

Whatever the explanation involved, our results suggest that differences of nitrogen supply between control and field experiment should be studied in more detail in order to transpose results from potted saplings to natural regeneration. We also need to avoid limitation of root growth by using larger pots. Another limit of this transposition is the low number of irradiance levels for the potted saplings in southern France, resulting in an approximation of the estimation of the relation of photosynthetic apparatus characteristic and relative irradiance.

\section{CONCLUSION}

Our objective was to study the response of beech to light regime in the context of Mediterranean climate. In this aim we studied a young regeneration in understory of a natural stand, and saplings grown in artificial shading. The main result was a very higher nitrogen allocation to photosynthesis of the saplings in natural regeneration than the fertilised potted saplings. It suggests that responses of the photosynthesis apparatus versus irradiance of beech is very dependent of nitrogen availability or others microclimate traits. This phenomenon should be taken in consideration when studying the acclimation of beech to Mediterranean climate in field conditions of the slopes of Mont-Ventoux mountain. The characterisation of shade tolerance of beech in the Mediterranean climate context should be further studied by taking in account the different soils conditions and microclimate environments.

\footnotetext{
Acknowledgements: This research was funded by the EC fifth Framework Programme, research contract "DynaBeech: Effects of silvicultural regimes on dynamics of genetic and ecological diversity of European beech forests" (QLK5-CT-1999-1210). We thank Erwin Dreyer for his helpful comments and critical readings of the manuscript. Oliver Brendel is gratefully acknowledged for valuable language revision. We also thank Annabel Porté for providing data from hemispherical photography, Arnaud Jouineau and Jacqueline Marchand for technical assistance.
}

\section{REFERENCES}

[1] Abrams M.D., Kubiske M.E., Leaf structural characteristics of 31 hardwood and conifer tree species in central Wisconsin: influence of light regime and shade-tolerance rank, For. Ecol. Manage. 31 (1990) 245-253.

[2] Aranda I., Bergasa L.F., Gil L., Pardos J.A, Effects of relative irradiance on the leaf structure of Fagus sylvatica L. saplings planted in the understory of a Pinus sylvestris L. stand after thinning, Ann. For. Sci. 58 (2001) 673-680.

[3] Aussenac G., Ducrey M., Étude bioclimatique d'une futaie feuillue (Fagus silvatica L. et Quercus sessiliflora Salisb.) de l'est de la France : I - Analyse des profils microclimatiques et des caractéristiques anatomiques et morphologiques de l'appareil foliaire, Ann. Sci. For. 41 (1977) 265-284.

[4] Bazzaz F.A., The physiological ecology of plant succession: A comparative review, Annu. Rev. Ecol. Syst. 10 (1979) 351-371.

[5] Boardman N.K., Comparative photosynthesis of sun and shade plants, Annu. Rev. Plant Physiol. 28 (1977) 355-377.

[6] Bond B.J., Farnsworth B.T., Coulombe R.A., Winner W.E., Foliage physiology and biochemistry in response to light gradients in conifers with varying shade tolerance, Oecologia 120 (1999) 183-190.

[7] Clearwater M.J., Meinzer F.C., Relationships between hydraulic architecture and leaf photosynthetic capacity in nitrogen-fertilized Eucalyptus grandis trees, Tree Physiol. 21 (2001) 683-690.

[8] Curt T., Coll L., Prévosto B., Balandier P., Kunstler G., Plasticity in growth, biomass allocation and root morphology in beech seedlings as induced by irradiance and herbaceous competition, Ann. For. Sci. 62 (2005) 51-60.

[9] Dreyer E., LeRoux X., Montpied P., Daudet F.A., Masson F., Temperature response of leaf photosynthetic capacity in saplings from seven temperate tree species, Tree Physiol. 21( 2001) 223-232.

[10] Dreyfus P., Gestion d'une évolution forestière majeure de l'arrièrepays méditerranéen : la maturation sylvigénétique des pinèdes pionnières ; conséquences pour la biodiversité sur le site pilote du Mont-Ventoux, Programme «Biodiversité et gestion forestière » du GIP Ecofor, 2001.

[11] Ducrey M., Variation in leaf morphology and branching pattern of some tropical rain forest species from Guadeloupe (French West Indies) under semi-controlled light conditions, Ann. Sci. For. 49 (1992) 553-570.

[12] Du Merle P., Le massif du Ventoux, Vaucluse : éléments d'une synthèse écologique, La Terre et la Vie, Revue d'Écologie appliquée 32 (1978) 7-295.

[13] Dungan R.J., Whitehead D., Duncan R.P., Seasonal and temperature dependence of photosynthesis and respiration for two cooccurring broad-leaved tree species with contrasting leaf phenology, Tree Physiol. 23 (2003) 561-568.

[14] Epron D., Godard D., Cornic G., Genty B., Limitation of net $\mathrm{CO}_{2}$ assimilation rate by internal resistances to $\mathrm{CO}_{2}$ transfer in the leaves of two tree species (Fagus sylvatica L. and Castanea sativa Mill.), Plant Cell Environ. 18 (1995) 43-51.

[15] Epron D., Liozon R., Mousseau M., Effects of elevated $\mathrm{CO}_{2}$ concentration on leaf characteristics and photosynthetic capacity of beech (Fagus sylvatica) during the growing season, Tree Physiol. 16 (1996) 425-432.

[16] Evans J.R., Photosynthesis and nitrogen relationships in leaves of $\mathrm{C}_{3}$ plants, Oecologia 78 (1989) 9-19.

[17] Evans J.R., Poorter H., Photosynthetic acclimation of plants to growth irradiance: the relative importance of specific leaf area and nitrogen partitioning in maximizing carbon gain, Plant Cell Environ. 24 (2001) 755-767.

[18] Farquhar G.D., von Caemmerer S., Berry J.A., A biochemical model of $\mathrm{CO}_{2}$ assimilation in leaves of $\mathrm{C}_{3}$ species, Planta 149 (1980) 78-90. 
[19] Frazer G.W., Canham C.D., Lertzman K.P., Gap Light Analyser (GLA), Version 2.0: Imaging software to extract canopy structure and gap light transmission indices from true-colour fisheye photographs, users manual and program documentation, Copyright 1999, Simon Fraser University, Burnaby, British Columbia, and the Institute of Ecosystem Studies, Millbroock, New York, 1999.

[20] Givnish T.J., Adaptation to sun and shade: a whole plant perspective, Aust. J. Plant Physiol. 15 (1988) 63-92.

[21] Grassi G., Bagnaresi U., Foliar morphological and physiological plasticity in Picea abies and Abies alba saplings along a natural light gradient, Tree Physiol. 21 (2001) 959-967.

[22] Grassi G., Meir P., Cromer R., Tompkins D., Jarvis J.G., Photosynthetic parameters in saplings of Eucalyptus grandis as affected by rate of nitrogen supply, Plant Cell Environ. 25 (2002) 1677-1688.

[23] Grassi G., Vicinelli E., Ponti F., Cantoni L., Magnani F., Seasonal and interannual variability of photosynthetic capacity in relation to leaf nitrogen in a deciduous forest plantation in northern Italy, Tree Physiol. 25 (2005) 349-360.

[24] Han Q., Kawasaki T., Nakano T., Chiba Y., Spatial and seasonal variability of temperature responses of biochemical photosynthesis parameters and leaf nitrogen content within a Pinus densiflora crown, Tree Physiol. 24 (2004) 737-744.

[25] Harley P.C., Tenhunen J.D., Modeling the photosynthetic response of $\mathrm{C}_{3}$ leaves to environmental factors, in: Modeling crop photosynthesis - from biochemistry to canopy, vol. 19, American Society of Agronomy and Crop Science Society of America, Madison, Wis., 1991, pp. 17-39.

[26] Jayasekera R., Schleser G.H., Seasonal changes in potential net photosynthesis of sun and shade leaves of Fagus sylvatica L., J. Plant Pysiol. 133 (1988) 216-221.

[27] Johnson J.D., Tognetti R., Michelozzi M., Pinzauti S., Minotta G., Borghetti M., Ecophysiological responses of Fagus sylvatica saplings to changing light conditions: II. The interaction of light environment and soil fertility on seedling physiology, Physiol. Plantarum 101 (1997) 124-134.

[28] Kloeppel B.D., Abrams M.D., Kubiske M., Seasonal ecophysiology and leaf morphology of four successional Pennsylvania barrens species in open versus understory environments, Can. J. For. Res. 23 (1993) 181-189.

[29] Koike T., Kitao M., Maruyama Y., Mori S., Lei T., Leaf morphology and photosynthetic adjustments among deciduous broad-leaved trees within the vertical canopy profile, Tree Physiol. 21 (2001) 951-958.

[30] Le Roux X., Grand S., Dreyer E., Daudet F.A., Parameterization and testing of a biochemically based photosynthesis model for walnut (Juglans regia) trees and saplings, Tree Physiol. 19 (1999) 481-492.

[31] Le Roux X., Walcroft A.S., Daudet F.A., Sinoquet H., Chaves M.M., Rodrigues A., Osorio L., Photosynthetic light acclimation in peach leaves: importance of changes in mass: area ratio, nitrogen concentration, and leaf nitrogen partitioning, Tree Physiol. 21 (2001) 377-386.

[32] Masarovicova E., Minarcic P., Photosynthetic response and adaptation of Fagus sylvatica L. trees to light conditions: 2. Leaf chlorophyll contents, leaf dry matter, specific leaf area and mass, stomatal density, Biologia [Bratislava] 40 (1985) 473-481.

[33] Medlyn B.E., Loustau D., Delzon S., Temperature response of parameters of a biochemically based model of photosynthesis, I. Seasonal changes in mature maritime pine (Pinus pinaster Ait.), Plant Cell Environ. 25 (2002) 1155-1165.

[34] Meir P., Kruijt B., Broadmeadow M., Barbosa E., Kull O., Carswell F., Norbe A., Jarvis P.G., Acclimation of photosynthetic capacity to irradiance in tree canopies in relation to leaf nitrogen concentration and leaf mass by unit area, Plant Cell Environ. 25 (2002) 343-357.

[35] Messier C., Doucet R., Ruel J.C., Claveau Y., Kelly C., Lechowicz M.J., Functional ecology of advance regeneration in relation to light in boreal forests, Can. J. For. Res. 29 (1999) 812-823.
[36] Millard P., The accumulation and storage of nitrogen by herbaceous plants, Plant Cell Environ. 11 (1988) 1-8.

[37] Niinemets Ü., Distribution of foliar carbon and nitrogen across the canopy of Fagus sylvatica: adaptation to a vertical light gradient, Acta Oecologica 16 (1995) 525-541.

[38] Niinemets Ü., Role of foliar nitrogen in light harvesting and shade tolerance of four temperate deciduous woody species, Funct. Ecol. 11 (1997) 518-531.

[39] Niinimets Ü., Kull O., Stoichiometry of foliar carbon constituents varies along light gradients in temperate woody canopies: implications for foliage morphological plasticity, Tree Physiol. 18 (1998) 467-479.

[40] Niinemets Ü., Tenhunen J.D., A model separating leaf structural and physiological effects on carbon gain along light gradients for the shade tolerant species Acer saccharum, Plant Cell Environ. 20 (1997) 845-866.

[41] Niinimets Ü., Kull O., Tenhunen J.D., An analysis of light effects on foliar morphology, physiology, and light interception in temperate deciduous woody species of contrasting shade tolerance, Tree Physiol. 18 (1998) 681-696.

[42] Piel C., Frak E., Le Roux X., Genty B., Effect of local irradiance on $\mathrm{CO}_{2}$ transfer conductance of mesophyll in walnut, J. Exp. Bot. 53 (2002) 2423-2430.

[43] Reich P.B., Walters M.B., Ellsworth D.S., Uhl C., Photosynthesisnitrogen relations in Amazonian tree species: I. Patterns among species and communities, Oecologia 97 (1994) 62-72, II. Variation in nitrogen vis-a-vis specific leaf area influences mass- and areabased expression, Oecologia 97 (1994) 73-81.

[44] Rijkers T., Pons T.L., Bongers F., The effect of tree height and light availability on photosynthetic leaf traits of four neotropical species differing in shade tolerance, Functional Ecology 14 (2000) 77-86.

[45] Sestak Z., Ticha I., Catsky J., Solarova J., Posposilova J., Hodanova J., Integration of photosynthetic characteristics during leaf development, in: Sestak Z. (Ed.), Photosynthesis during leaf development, Dr W. Junk Publishers, Dordrecht, Netherlands, 1985, pp. 263-286.

[46] Stenberg P., Smolander H., Sprugel D., Smolander S., Shoot structure, light interception, and distribution of nitrogen in a Abies amabilis canopy, Tree Physiol. 18 (1998) 759-767.

[47] Tognetti R., Minotta G., Pinzauti S., Michelozzi M., Borghetti M., Acclimation to changing light conditions of long-term shade-grown beech (Fagus silvatica L.) seedlings of different geographic origins, Trees 12 (1998) 326-333.

[48] Uemura A., Ishida A., Nakano T., Terashima I., Tanabe H., Matsumoto Y., Acclimation of leaf characteristics of Fagus species to previousyear and current-year solar irradiances, Tree Physiol. 20 (2000) 945-951.

[49] Walcroft A., Le Roux X., Diaz-Espejo A., Dones N., Sinoquet H., Effects of crown development on leaf irradiance, leaf morphology and photosynthetic capacity in a peach tree, Tree Physiol. 22 (2002) 929-938.

[50] Walcroft A.S., Whitehead D., Silvester W.B., Kelliher F.M., The response of photosynthetic model parameters to temperature and nitrogen concentration in Pinus radiata D. Don., Plant Cell Environ. 20 (1997) 1338-1348.

[51] Warren C.R., Dreyer E., Adams M.A., Photosynthesis-Rubisco relationships in foliage of Pinus sylvestris in response to nitrogen supply and the proposed role of Rubisco and amino acids as nitrogen stores, Trees 17 (2003) 359-366.

[52] Wilson K.B., Baldocchi D.D., Hanson P.J., Spatial and seasonal variability of photosynthetic parameters and their relationship to leaf nitrogen in a deciduous forest, Tree Physiol. 20 (2000) 565578.

[53] Xu L., Baldocchi D.D., Seasonal trends in photosynthetic parameters and stomatal conductance of blue oak (Quercus douglasii) under prolonged summer drought and high temperature, Tree Physiol. 23 (2003) 865-877. 